\title{
The Effect of State Anti-Predatory Lending Laws on the Mortgage Market
}

\author{
Amina Enkhbold \\ University of Toronto \\ 150 St. George Street Toronto, Canada
}

\begin{abstract}
I study the impact of state anti-predatory lending (APL) laws on the expansion of riskier loans. Banks were supplying low quality mortgages to risky borrowers via predatory practices, such as refinancing with higher fees, lending without regard for the ability to repay and inflating property values above the market price.In response to predatory lending practices, states began implementing APL laws between 1999 to 2006. However, this legislation was partially offset when the Office of the Comptroller Currency (OCC) exempted national banks from APL laws in 2004. I use the 2004 federal preemption rule, as an exogenous shock to assess the causal impact of APL laws on the mortgage market via national banks. I find that after the federal preemption rule, higher growing national banks increase loan origination by $10 \%$ relative to state banks. National banks increase the private share by $1.8 \%$ and the growth in marginal GSE by $3 \%$ in states with tougher APL laws.
\end{abstract}

Keywords: anti-predatory lending law; mortgage securitization

JEL Codes: G21, G28, K23

\section{Introduction}

Banks were engaged in predatory lending practices-refinance with higher fees, inflate property values above the market price, lend without regard for the ability to repay-on subprime mortgage borrowers. Starting 1999, a number of states implemented anti-predatory lending (APL) laws. APL laws restrict banks to prey on low-income and elderly borrowers by requiring verification of borrowers' repayment ability and having limits on fees, rates and prepayment penalties. However, APL laws failed to prevent the subprime mortgage crisis as the Office of the Comptroller Currency (OCC) exempted national banks from APL laws in2004.

In this paper, I ask: what are the effects of APL laws on mortgage loan originations and securitization? One of the major difficulties in empirically identifying the effect of deregulation on mortgage loan originations and securitizations is that most federal policy interventions affect all lenders at once. I overcome this problem by using the OCC preemption rule-when the OCC exempted national banks in 2004, while non-OCC lenders (state banks, credit unions, non-depository mortgage companies) are covered by APL laws-as an exogenous shock. The OCC preemption rule targets predatory mortgage lending on riskier borrowers. This preemption rule creates an environment to test the effects of partial deregulation by distinguishing between affected and unaffected lenders, thereby allowing us to evaluate the direct effects of the policy on mortgage originations and securitizations.

My panel dataset merges data at the regulator-metropolitan statistical area (MSA) level from years 2002 to 2006. I use private and marginal GSE loans (loans where credit score is below 620) from the Home Mortgage Disclosure Act (HMDA) and Freddie Mac and Fannie Mae, bank balance sheet from Call Reports and APL law indices from Bostic,Engel, McCoy, Pennington-Cross, \& Wachter (2008).

I use the OCC preemption rule as the credit shock, where national banks are the key drivers in lending to riskier borrowers. I analyze the mortgage market in APL and non-APL states before and after the OCC preemption rule by exploiting heterogeneous presence of national banks and regional variation in the strength of APL intensities. This approach controls for national trends affecting national banks and sorting by banks across states in response to prior APL laws. I find that after the preemption rule, higher growing national banks increase loan origination by $10 \%$ relative to non-OCC lenders. National banks increase the private share by $1.8 \%$ and the growth in marginal GSE by 3\% in states with tougher APL laws. Throughout the paper, I use OCC lenders for national banks and non-OCC lenders for state banks which include state banks, credit unions and non-depository mortgage companies. 
The outline of the rest of the paper is as follows. Section 2 describes state anti-predatory lending laws and discusses the literature. Section 3 describes the market structure. Section 4 discusses the data sources and Section 5 illustrates empirical methodology. Section 6 reports results and Section 7 concludes. List of figures and tables is shown in section 8 .

\section{Background}

State Anti-predatory Lending Laws

Predatory lending involves practices such as charging borrowers high fees, arranging borrowers to refinance where they would pay a higher amount in later years, making a loan without considering the borrower's paying ability or adding subprime prepayment penal- ties that increase the risk of foreclosure (Ding, Quercia, Reid, \& White, 2012). In 1994, the U.S. Congress enacted an anti-predatory lending statute, the Home OwnershipEquity Protection Act (HOEPA). HOEPA applies to all residential mortgage lenders and brokers. It regulates high-cost loans based on annual percentage rate or when total points and fees exceed eight percent of the total loan amount or $\$ 400$ whichever is greater. It covers less than five percent of subprime residential mortgages and imposes a number of restrictions within these loans. However, lenders learned to avoid the high-cost loan provisions easily. As a result, many states implemented their own APL laws based on HOEPA. Implementation and regulation of APL laws vary across states, time, and intensities. By January 1, 2007 only six states did not legislate any APL laws. APL laws target high-cost loans; according to HMDA, 37.4\% of all loans were high cost loans in 2004, $35.8 \%$ in 2005 and $40.9 \%$ in 2006. In 2004, the OCC exempted national banks from APL laws. Since the OCC depends on fees from their regulated entities, it was aware that if it did not grant preemption to national banks then they would switch their charter from the OCC to the Office of Thrift Supervision. The Office of Thrift Supervision preempted thrift institutions from APL laws in1996.Thus, only state-chartered depository institutions and independent mortgage lenders (non-OCC lenders) are regulated by state APL laws.

\section{Related Literature}

When North Carolina implemented the first new APL law in 1999, a literature soon emerged analyzing the impact of APL laws on mortgage loan applications, originations and rejections. Ho \& Pennington-Cross (2006) created APL laws indices in terms of coverage and restriction, while Bostic et al. (2008) updated the index with enforcement mechanism. The papers in this literature focus on loan originations, but it is vital to understand that APL laws target high-cost loans, which have interest rates three or more percentage points higher than the Treasury rate. Since APL laws target riskier loans, looking at overall loan originations may miss the true effect. According to Loan Performance, 51\% of all loans were subprime loans by 2002 (Quercia et al., 2003) and Federal Reserve report that $25 \%$ of all mortgages were subprime loans by 2005 (Avery et al.,2006). I use triple-difference strategy that is also employed in Di Maggio \& Kermani (2017), but this paper differs in both focus and results. I focus on loan originations and risky loans proxied by securitization, while Di Maggio \& Kermani(2017) focus on loan issuance, housing price, employment in non-tradable sector and loan delinquency. Di Maggio \& Kermani (2017) find the OCC preemption rule increases loan issuance by $11 \%$ to $15 \%$, while I find that only higher growing national banks increase loan origination by $10 \%$ relative to state banks. The following four reasons will explain the different magnitude of loan issuance.

\section{Figure 1: Deposit to asset ratio}

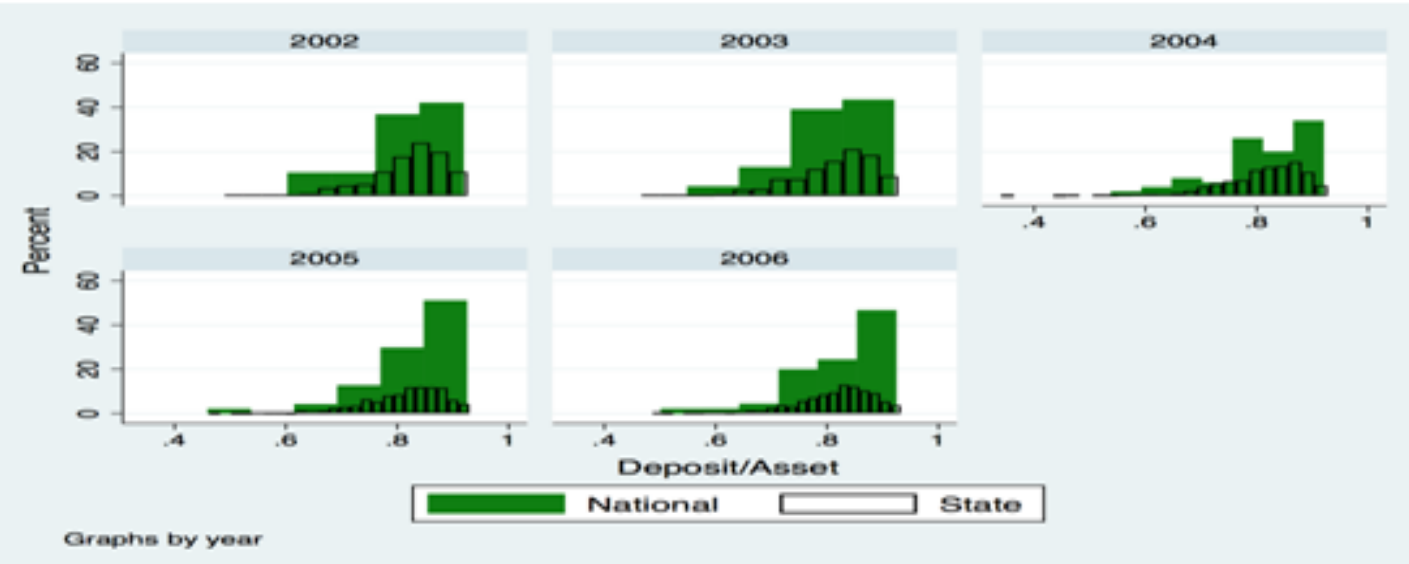


First, Di Maggio \& Kermani (2017) do not incorporate bank size information, but large lenders such as Wells Fargo, JPMorgan Chase, Bank of America and US Bancorp were heavily involved in high risky lending. From figure 1, we can see that national banks (OCC lenders) have higher deposit to asset ratio than state banks (nonOCC lenders). Thus, I incorporate bank deposit and asset information.

Second, the larger effects of loan issuance from Di Maggio \& Kermani (2017) maybe due to different method. They use weighted-least squares regression with weights equal to the population of each county. If APL laws tend to have larger effects in more populous states, then WLS estimation that places greater weight on more populous states will tend to estimate larger effects than OLS does. However, HMDA is a representative data that is based on the location of the house purchased. They also use county population as a weight rather than the inverse of the population. Using the inverse of population would reflect the information in the observation, because an observation with small error variance has a large weight since it contains relatively more information than an observation with large error variance .But, both OLS and WLS are inconsistent for the population average effect and neither strictly dominates the other. Thus, I report OLS, OLS with robust standard errors and WLS results in table 1 and compare their standard errors. OLS standard errors are smaller than WLS standard error.

Table 1: Replication of Di Maggio and Kermani (2017)

\begin{tabular}{llll}
\hline & \multicolumn{2}{l}{ OLS } & \multicolumn{2}{l}{ OLS, robustWLS, robust } \\
& $(1)$ & $(2)$ & $(3)$ \\
\hline APL & $-0.056^{* *}-0.056^{* *}$ & -0.030 \\
& $(0.03)$ & $(0.03)$ & $(0.03)$ \\
OCC & -0.088 & -0.088 & $0.128^{*}$ \\
& $(0.06)$ & $(0.06)$ & $(0.07)$ \\
APL $\times$ OCC & -0.001 & -0.001 & $-0.204^{* *}$ \\
& $(0.08)$ & $(0.08)$ & $(0.09)$ \\
APL $\times$ OCC $\times$ Post-0.055 & -0.055 & 0.144 \\
& $(0.10)$ & $(0.10)$ & $(0.12)$ \\
APL $\times$ Post & 0.030 & 0.030 & 0.034 \\
& $(0.05)$ & $(0.05)$ & $(0.05)$ \\
OCC $\times$ Post & 0.050 & 0.050 & -0.112 \\
& $(0.08)$ & $(0.08)$ & $(0.09)$ \\
\hline$R^{2}$ & 0.158 & 0.158 & 0.112 \\
$N$ & 105288 & 105288 & 105288 \\
County FE & Yes & Yes & Yes \\
Year FE & Yes & Yes & Yes \\
\hline
\end{tabular}

Third, they analyze APL adoption dates on home purchase loans. However, APL laws target subprime mortgage market and analyzing the impact of APL laws on securitized and unsecuritized mortgage loans would be a better measure than home purchase loans. They also include fraction of subprime borrowers in each county as a control variable, but the fraction of subprime borrowers are affected by the APL laws. In my paper, I exploit the variation in APL intensities and analyze it on subprime mortgage loans and total loan originations defined as the sum of securitized and unsecuritized mortgage loans. Lastly, they choose states with APL laws that are built on HOEPA, thus leaving 9 other states with APL laws. I incorporate all states with APL laws.

\section{Market Structure}

To provide the underpinnings for the empirical work, this section reviews how APL laws affect households, lenders and securitizers' decisions. Figure 2 shows the market structure: households purchase mortgage loans either from OCC lenders or non-OCC lenders that are regulated by APL laws. Lenders can hold or sell mortgage loans to either government- sponsored enterprise (GSE) or private securitizers. 


\section{Competition}

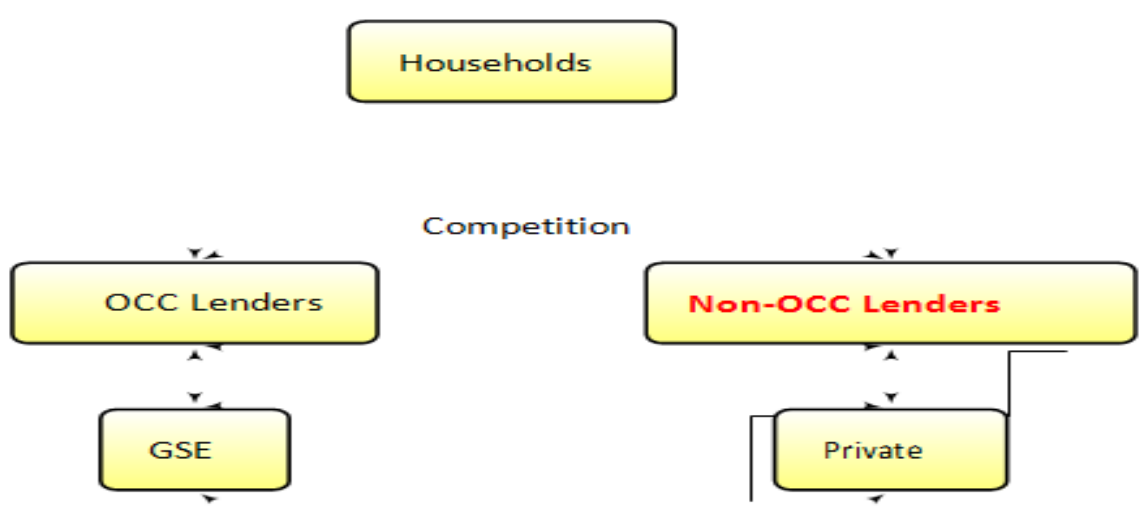

Fig 2. Market Structure. Notes: OCC lenders consist of national chartered commercial banks that were exempted from APL laws by regulator, Office of Comptroller Currency (OCC), in 2004, while non-OCC lenders consist of state banks, credit unions and non-depository mortgage companies that are not preempted from APL laws. GSE is a government- sponsored enterprise that composes of Fannie Mae and Freddie Mac. GSE is required to purchase low risky loans, while private securitizers buy riskier loans. GSE securities are insulated from default risk, while private securitizers must price both the risk of default and risk of early prepayment.

Households differ in their search costs. One with lower search cost would shop around and choose any bank that offers the lowest interest rate, while a household with higher search cost would most likely take mortgage loans from a pre-existing relationship through savings or deposit account. APL laws allow households to sort loans from predatory loans. The press, government reports and local nonprofit agencies have informed the public about the presence of predatory lending but regulatory agencies found some evidence that some subprime borrowers, particularly elderly or poorly educated households, were unable to sort predatory loans (Ho \& Pennington-Cross, 2006).

\section{Hypotheses}

Non-OCC lenders can transfer the cost imposed by APL laws to borrowers or bear the cost on their own. If they transfer the cost to borrowers, it would be cheaper to purchase from OCC lenders and OCC lenders' loan originations would increase. If non-OCC lenders bear the cost on their own, borrowers are likely to take out loans from non-OCC lenders due to reduced legal uncertainty. It would be ideal for researchers to observe mortgage pricing or interest rates at each lender to confirm the hypothesis. I test this hypothesis by estimating loan origination on APL laws.

Lenders:

Transfer the lending cost: Non-OCC lenders that face APL laws can transfer the cost to borrowers which would increase the price of loans. Thus, borrowers take mortgage loans from OCC lenders. Swallow the lending cost: Non-OCC lenders can bear the costs imposed by APL laws. Since APL laws reduced legal uncertainty, borrowers are fearless to take loans from non-OCC lenders. GSE and private securitizers maximize profits for stockholders, but GSE is constrained to purchase good quality loans. If GSE concerns about the public then it securitizes lessrisky loans. If GSE focuses on retaining its market share then GSE would securitize riskier loans. Thus, race to the bottom competition happens between GSE and private securitizers. I test this hypothesis by estimating loan securitization on APL laws.

Securitizers: Public Concern: Lenders offer securitizers with different risks in terms of credit score, loan-tovalue(LTV) and debt-to-income(DTI).Securitizers choose the package that most closely fits their objectives. For example, if GSE concerns about public it may prefer lenders with less-risky borrowers while private securitizers that want to maximize profits may prefer high-risky borrowers.

Race to the bottom: If GSE solely concentrates on retaining its market share, then GSE and private securitizers will compete for lenders. Banks would take excessive risks by providing low quality loans to riskier borrowers. This is not in the public interest because it increases the risk of bank failures and future tax payment for bailouts. 


\section{Data}

In this section, I provide an overview of the different datasets used in this paper. Annual panel dataset at the MSA level is built from a variety of public sources. I use MSA level data because social and economic integration are much more accurate than state-level data. I collect mortgage loan originations and securitization from the Home Mortgage Disclosure Act (HMDA), GSE securitized loans from Fannie Mae and Freddie Mac, bank size information from Call Reports, population data from Bureau of Economic Analysis, employment rate and income from American Consumer Survey and housing supply elasticity from Saiz (2010). I use APL law intensities for years from 2004 to 2005 from Bostic et al. (2008). Legal measures that are equivalent to HOEPA get a score of 0, whereas higher scores indicate heavier regulation.

APL laws are measured in terms of coverage, restrictions and enforcement indices and all APL indices are standardized. HMDA provides number and volume of loan originations and securitization for financial institutions that are regulated by different agencies in the location of the purchased property. It indicates the regulators of lenders, thus I can identify OCC vs non- OCC lenders. HMDA is a disclosure report that is publicly available and used widely by academic and policy research. A lender does not have to report to HMDA, unless it has an office in a MSA or have less than $\$ 30$ million in assets. Banks are subject to pecuniary penalties if they do not report. There are two limitations in the HMDA dataset. It does not have any information on borrower characteristics and reportings on rural areas are low. To compare similar loans that are securitized by government and private labelers, I construct marginal GSE loans where credit score is below 620 from the Fannie Mae and Freddie Mac. Fannie Mae and Freddie Mac provide information on loan acquisition and origination at the quarterly frequency, respectively.

\section{Summary Statistics}

Table 2: Percentage of Financial Institutions at Bank-MSA Level OCCLenders Non-OCC Lenders (45\%)

\begin{tabular}{ccccc}
\cline { 2 - 3 } Year & OCC & & FRB & FDIC \\
\hline 2002 & 9 & & 15.6 & 75.4 \\
2003 & 9.4 & & 15.9 & 74.8 \\
2004 & 7 & 16.2 & 76.8 \\
2005 & 7 & 15 & 78 \\
2006 & 7 & 16.5 & 76.5 \\
\hline
\end{tabular}

Notes: FRB for Federal Reserve Board and FDIC stands for Federal Deposit Insurance Corporation.

Table 3: Annual Growth at Bank-MSA Level: 2002-2006

Non-OCC Lenders

\begin{tabular}{lllllll}
\hline Variable & Mean & S. D. & Pctile 25 & Median & Pctile 75 & Obs \\
\hline GSE Secur. & -8.8 & 27 & -25.8 & -9.4 & 2.9 & 674 \\
Private Secur. & .74 & 6.1 & 0 & 0 & 0 & 10 \\
Total Loan Orig. & -4.2 & 16.6 & -14.1 & -4.1 & 4.1 & 1287 \\
Asset & 2.38 & 4.75 & .82 & 1.87 & 3.18 & 1258 \\
Deposit & 2.33 & 4.79 & .72 & 1.74 & 3.3 & 1258 \\
\hline OCC Lenders & & & & & & \\
\hline Variable & Mean & S. D. & Pctile 25 & Median & Pctile 75 & Obs \\
\hline GSE Secur. & -9.1 & 27.2 & -26.3 & -10.5 & 5.5 & 49 \\
Private Secur. & 4.1 & 33.1 & -26.8 & 0 & 39 & 3 \\
Total Loan Orig. & -3.6 & 18.8 & -14 & -5 & 7.1 & 104 \\
Asset & 2.58 & 3.78 & .76 & 1.86 & 3.54 & 99 \\
Deposit & 2.57 & 3.85 & .65 & 1.97 & 3.65 & 99 \\
\hline
\end{tabular}

Table 4: Annual Growth at Regulatory-MSA Level: 2002-2006 


\begin{tabular}{|c|c|c|c|c|c|c|}
\hline \multicolumn{7}{|c|}{ Non-OCC Lenders } \\
\hline$\overline{\text { Variable }}$ & \multicolumn{6}{|c|}{ Mean S. D. Pctile 25 Median Pctile 75Obs } \\
\hline GSE Secur. & -4.5 & 27.3 & -21.4 & -6.9 & 9.9 & 683 \\
\hline Private Secur. & -.86 & 36.5 & -43.3 & 0 & 31.3 & 199 \\
\hline $\begin{array}{l}\text { Marginal } \\
\text { Secur. }\end{array}$ & E1.9 & 13.9 & -6.2 & 2.8 & 10.5 & 908 \\
\hline Total Loan Oriq & -2.6 & 17.1 & -11 & -2.1 & 6.8 & 754 \\
\hline \multicolumn{7}{|c|}{ OCC Lenders } \\
\hline Variable & Mean & S. D. & Pctile & $5 \mathrm{Med}$ & n Pctil & $750 b s$ \\
\hline GSE Secur. & -4.7 & 31.2 & -28.4 & -4.5 & 11.4 & 216 \\
\hline Private Secur. & 1.1 & 37.5 & -35.2 & 0 & 44.5 & 44 \\
\hline $\begin{array}{l}\text { Marginal } \\
\text { Secur. }\end{array}$ & E1.8 & 13.3 & -6.8 & 3.1 & 10.6 & 445 \\
\hline Total Loan Ori & -3.5 & 20.6 & -15.3 & -2.8 & 8.5 & 333 \\
\hline
\end{tabular}

I concentrate on the period from 2002 to 2006 for symmetrical analysis before and after the 2004 OCC preemption rule. Table 2 reports the percentage of financial institutions from my working sample. Since there is no public data on credit union and non-depository mortgage companies, I only include state-chartered banks that are regulated by Federal Reserve Board and Federal Deposit Insurance Corporation. This leaves me with $45 \%$ of non-OCC lenders. OCC lenders compose of less than $10 \%$, while state-chartered banks that are regulated by Federal Deposit Insurance Corporation take larger presence. Table 3 shows summary statistics of annual growth at bank-MSA level and table 4 reports it at regulatory-MSA level. In the bank-MSA level, OCC lenders have higher growth in private securitization than non-OCC lenders. In the regulator-MSA level, both types of lenders have similar pattern except for private securitization. OCC lenders have positive growth, while non-OCC lenders have negative growth in private securitization.

\section{Empirical Methodology}

In this section, I discuss the implication of APL laws on loan originations and securitizations by using a difference-in-difference-in-difference (DDD) strategy.

$\mathrm{Ymtr}=\alpha \mathrm{m}+\eta \mathrm{t}+\beta 1 \mathrm{OCCr}+\beta 2$ APLst $+\beta 3 \mathrm{OCCr} \times$ Post 2004

$+\beta 4$ APLst $\times$ OCCr $+\beta 5$ APLst $\times$ Post 2004

$+\beta 6$ APLst $\times$ Post $2004 \times \mathrm{OCCr}+\Gamma \mathrm{Xmt}+\mathrm{smtr}$

(1) where Ymtr includes loan originations and private and marginal GSE securitizations in MSA m and time $t$ fixed effects for years from 2002 to 2006 by regulator r. APLst includes APL law indices. Post2004 is one if after preemption rule year 2004 and zero otherwise and $\mathrm{OCCr}$ is a dummy variable indicating if lenders are regulated by OCC or not. Xmt includes control variables such as population, employment rate, housing supply elasticity and average income. Standard errors are clustered at MSA level. $\beta 1$ represents the differences between OCC and nonOCC lenders in non-APL states before preemption, $\beta 2$ represents the differences between APL states and nonAPL states, which captures the APL effect on mortgage performance before preemption. $\beta 3$ to $\beta 5$ capture the effects of different interactions on mortgage performance. $\beta 6$ shows the preemption effect on mortgage securitization by capturing the change in mortgage performance of OCC originations in APL states after OCC preemption. If OCC lenders in APL states start to lend less, it means that previously they were swallowing costs, but if they start to lend more, it means that they were passing on the costs. The main interested variable is $\beta 6$ :

$\left(\beta \_6\right)^{\wedge}=\left(y_{-}(A P L, O C C)^{\wedge} \text { Post-y_(APL,OCC }\right)^{\wedge}$ Pre $)-\left(y_{-}(\text {Non-APL,OCC })^{\wedge} \text { Post-y_(Non-APL,OCC }\right)^{\wedge}$ Pre $)-\left(y_{-}\right.$ (APL,Non-OCC)^Post-y_(APL,Non-OCC)^Pre)-(y_(Non-APL,Non-OCC) $)^{\wedge}$ Post-y_(Non-APL,Non-OCC)^Pre ) (2)Analysis of OCC lenders before and after the legislative change will assess the impact of APL laws on the mortgage market. However, other macro effects are confounded. One useful approach is to compare OCC lenders in APL states to OCC lenders in non-APL states. But, the gap between this comparison would capture other nonAPL factors that vary by state.

Comparing unaffected group, non-OCC lenders in APL states to non-OCC lenders in non-APL states would capture non-APL factors that affect mort- gage market prospects. Taking differences between these two comparisons should give the effect of APL laws on the mortgage market. This controls for changes in lending 
across states and changes in lending of all banks in APLstates. DDD controls for different trends for OCC and non-OCC combined with sorting across states based on prior APL laws and different state-level trends for APL vs. non- APL states. DDD estimates the effect of the OCC preemption rule provided that there is no other omitted variable that leads to higher growth of OCC vs. non-OCC lending in APL states relative to non-APL states. This would be violated if in APL states, lawmakers responded to the preemption rule by changing state regulation of non-OCC lenders. Since (1) does not account for compositional effect, I use market share of national banks in 2003 as a MSA exposure to the OCC preemption rule.

Ymtr $=\alpha \mathrm{m}+\eta \mathrm{t}+\beta 1$ OCC $2003+\beta 2$ APLst $+\beta 3$ OCC $2003 \times$ Post 2004

$+\beta 4$ APLst $\times$ OCC $2003+\beta 5$ APLst $\times$ Post 2004

$+\beta 6$ APLst $\times$ Post $2004 \times$ OCC $2003+$ smt (3)

where OCC2003 is the market share of national banks relative to the total lending in each MSA. This controls for ex ante differential incentives of lenders in different states to supply credit in MSA with high market share of OCClenders.

\section{Results}

To provide information on regulated and deregulated lenders' activities, tables 5, 6 and 7 show results on log of loan originations, private share and growth in marginal GSE from triple differences. Columns (1) and (2) control for MSA and year fixed effects, columns (3) and (4) control for MSA $\times O C C$ and year fixed effects and columns(5)and(6)control for OCCxyear and MSA fixed effects. After the preemption rule, OCC lenders in states with tougher coverage rule decreases log of loan origination by 0.3 relative to non-OCC lenders. Table 6 shows that OCClendersincreaseprivateshareby1.8\% instricterrestrictionsruleandtable7presents that OCC lenders increase the growth in marginal GSE by $3.2 \%$ and $4.7 \%$ in states with tougher coverage and enforcement rules. The federal preemption rule increases the growth of marginal GSE and private share for OCC lenders relative to non-OCC lenders. When OCC lenders are deregulated, they are more likely to take risks and thus sell their loans on the secondary mortgage market.

Table 5: DDD: Log of Loan Amount

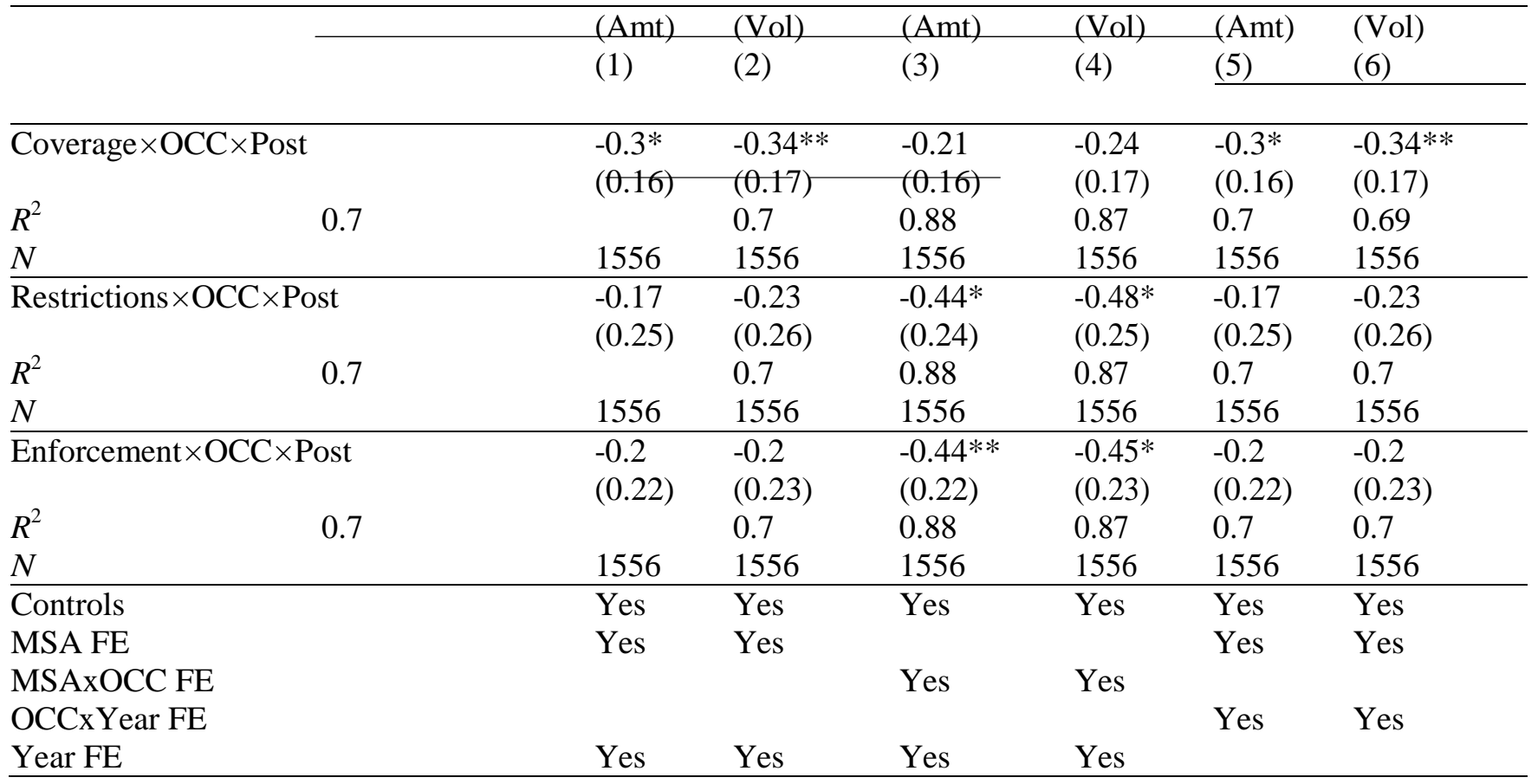

Notes: The sample includes years from 2002 to 2006. Standard errors are in parentheses and are clustered by MSA *** Significant at the 1 percent level. ** Significant at the 5 percent level. * Significant at the 1 percent level. 
Table 6: DDD: Private Share

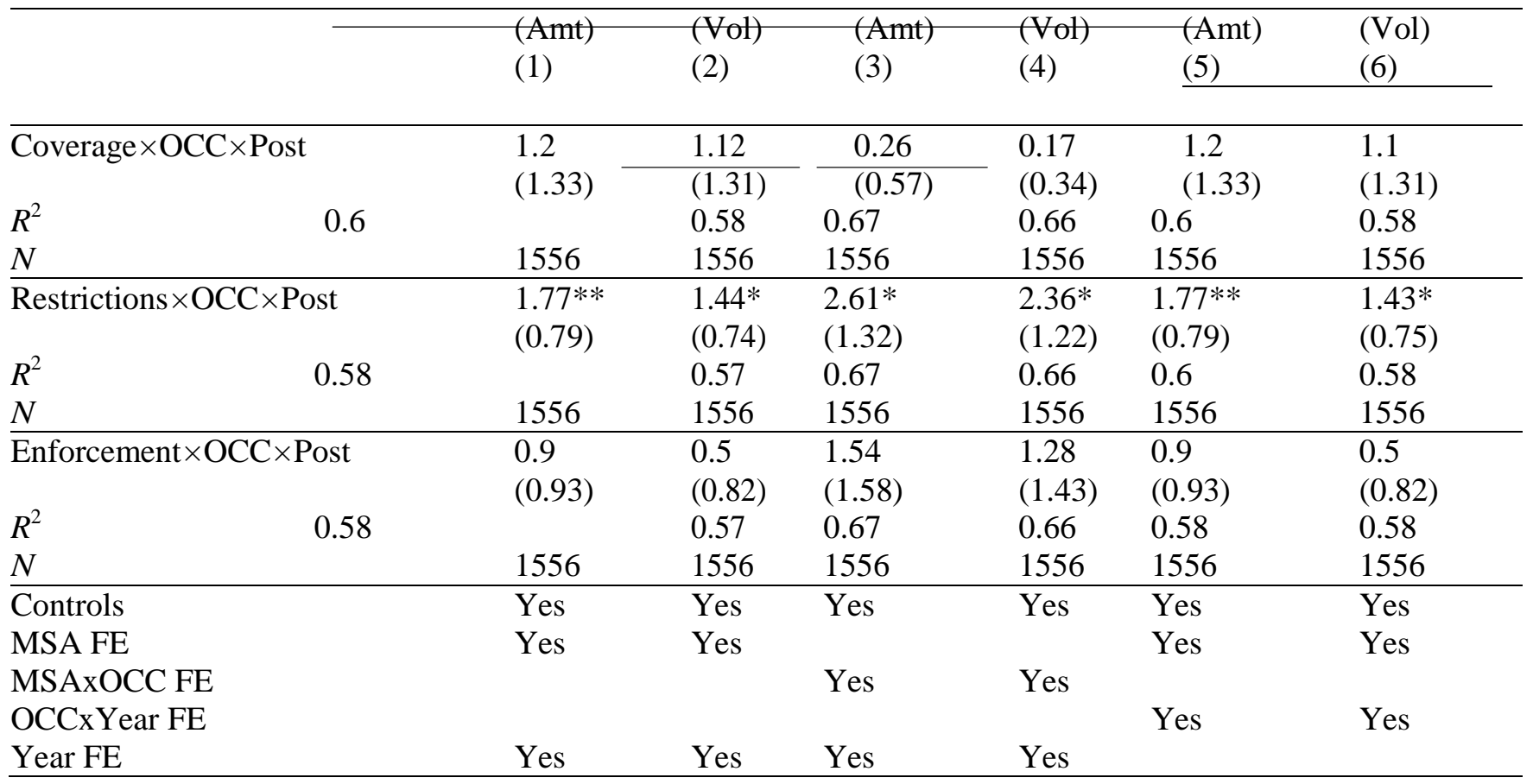

Notes: The sample includes years from 2002 to 2006. Standard errors are in parentheses and are clustered by MSA *** Significant at the 1 percent level. ** Significant at the 5 percent level. * Significant at the 1 percent level.

Table 7: DDD: Growth in Marginal GSE

\begin{tabular}{|c|c|c|c|}
\hline & $(1)$ & $(2)$ & (3) \\
\hline Coverage $\times \mathrm{OCC} \times \mathrm{Pos}$ & \multicolumn{3}{|c|}{$\begin{array}{r}3.2 * *(1.44) 3.79 * *(1.64) 3.2 * * \\
(1.44)\end{array}$} \\
\hline$R^{2}$ & 0.3 & 0.34 & 0.3 \\
\hline$N$ & 1353 & 1353 & 1353 \\
\hline Restrictions $\times \mathrm{OCC} \times \mathrm{P}$ & 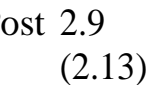 & $\begin{array}{l}3.5 \\
(2.64)\end{array}$ & $\begin{array}{l}3.02 \\
(2.12)\end{array}$ \\
\hline$R^{2}$ & 0.29 & 0.34 & 0.3 \\
\hline$N$ & 1353 & 1353 & 1353 \\
\hline \multicolumn{4}{|c|}{$\overline{\text { Enforcement } \times \text { OCC } \times \text { Post4.7** (1.93)4.89** (2.24)4.7** (1.93) }}$} \\
\hline$R^{2}$ & 0.29 & 0.34 & 0.3 \\
\hline$N$ & 1353 & 1353 & 1353 \\
\hline Controls & Yes & Yes & Yes \\
\hline MSA FE & Yes & & Yes \\
\hline MSAxOCC FE & & Yes & \\
\hline OCCxYear FE & & & Yes \\
\hline Year FE & Yes & Yes & \\
\hline
\end{tabular}

Notes: The sample includes years from 2002 to 2006. Standard errors are in parentheses and are clustered by MSA *** Significant at the 1 percent level. ** Significant at the 5 percent level. * Significant at the 1 percent level. 
Table 8: MSA Exposure to Preemption Rule

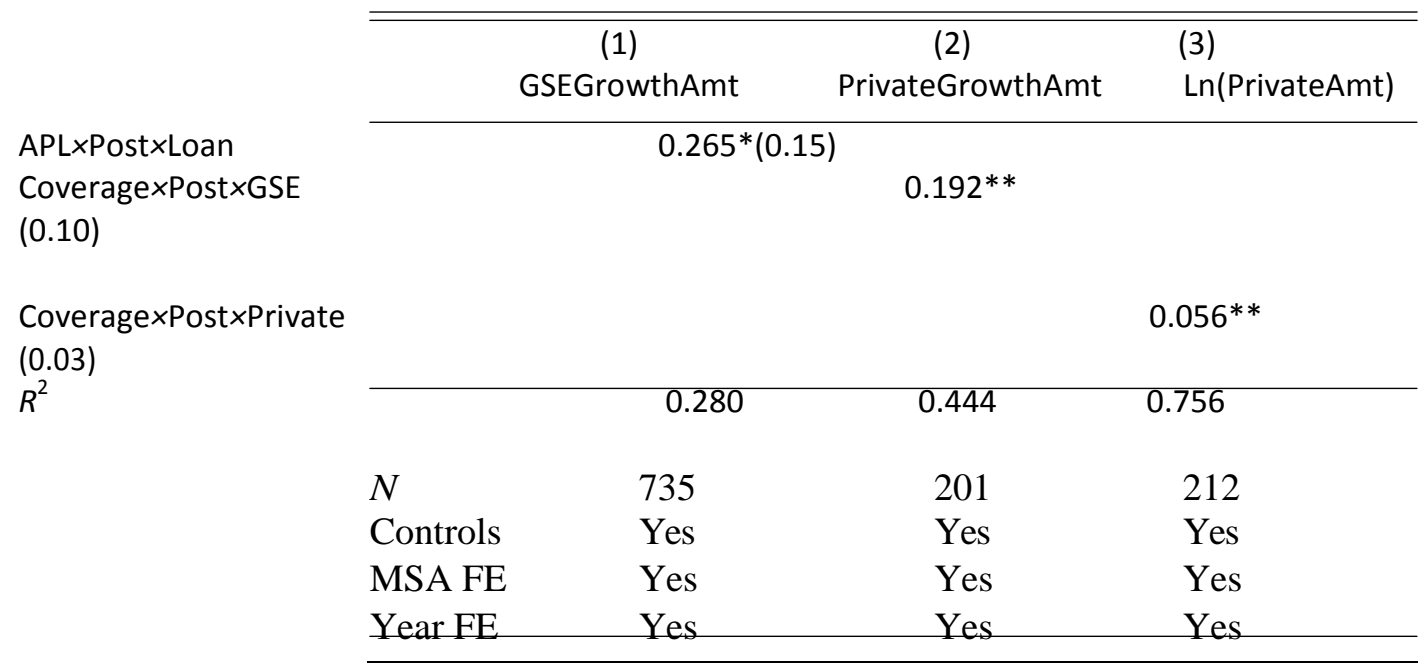

Second, I add MSA $\times$ OCC fixed effect. This captures shocks that affect only a subset of lenders in each MSA. This removes the possibility that OCC lenders may always grow faster than non-OCC lenders within the same MSA. For instance, some banks may advertise more in specific areas or exploit their geographical locations, thus increasing their mortgage growth. Table 5 presents that log of loan origination decreases by 0.4 in states with stricter restrictions or enforcement rules. Table 6 shows that OCC lenders increase private share by $2.6 \%$ more than non-OCC lenders in states with tougher restrictions rule and table 7 shows that OCC lenders increase growth in marginal GSE by $3.8 \%$ and $4.9 \%$ in states with stricter coverage and enforcement rules. Similar pattern holds when controlling for OCCxyear and year fixed effects. OCC xyear fixed effect captures time-varying unobserved heterogeneity for lenders. To account for compositional effect, I control for market share of OCC lenders in each MSA prior to the preemption rule. The results indicate that higher market share of OCC lenders in APL states resulted in larger increases in securitization. Table 8 shows that higher loan origination share resulted in higher GSE growth for OCC lenders relative to non-OCC lenders by $0.27 \%$. APL states with stricter coverage rule and higher growth in GSE or private securitization resulted in more private securitization by $0.2 \%$.

Table 9: Triple Differences at Bank-MSA Level

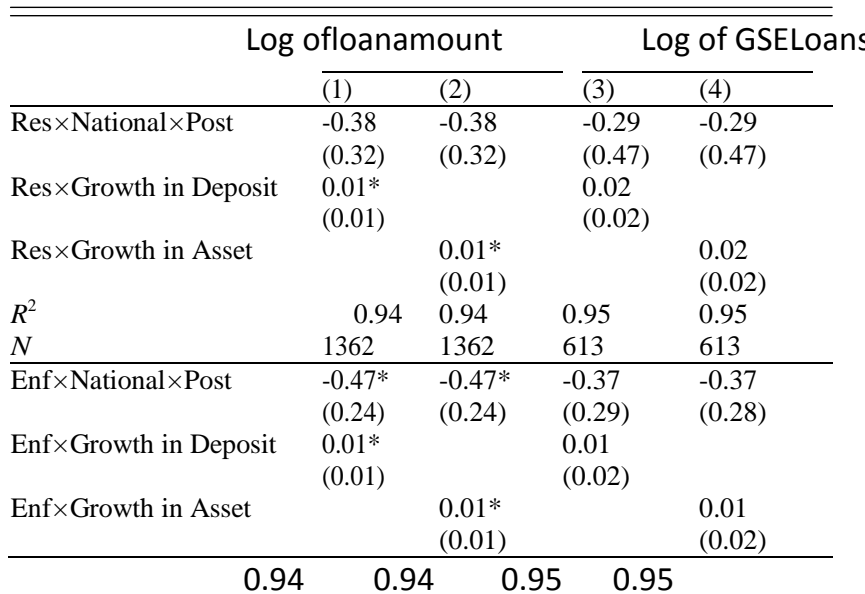

$\begin{array}{lcccc}N & 1362 & 1362 & 613 & 613 \\ \text { Controls } & \text { Yes } & \text { Yes } & \text { Yes } & \text { Yes } \\ \text { MSA FE } & \text { Yes } & \text { Yes } & \text { Yes } & \text { Yes } \\ \text { Bank FE } & \text { Yes } & \text { Yes } & \text { Yes } & \text { Yes } \\ \text { Year FE } & \text { Yes } & \text { Yes } & \text { Yes } & \text { Yes }\end{array}$


Furthermore, to rule out reverse causality I include the growth of a bank asset (size) and deposit information (lending capacity) to the set of control variables. Banks with strong loan demand open or purchase new branches to fund loan growth. Large banks with more capital could take higher risks since they are not financially constrained. Taking bank deposit or asset as a control variable, Table 9 shows that national banks with higher growth in asset or deposit increase loan originations by $10 \%$, whereas without controlling for bank balance sheet information, national banks decrease loan originations by $30 \%$.

\section{Conclusion}

It is vital to understand how regulatory institutional change can have heterogenous effects on banking activities. Studying regulations on banking can help us understand the origin of crisis and avoid it in the future. In this paper, I use the OCC preemption rule, when the OCC regulator exempted national banks in 2004,as a quasinatural experiment to study the impact of APL laws on loan originations and securitization. The purpose of this analysis is to assess the impact of APL laws on banks by decomposing lenders into regulated vs. deregulated types and to study their activities.

I find that after the preemption rule, OCC lenders decrease loan origination but higher growing national banks increase loan origination by $10 \%$ relative to non-OCC lenders. OCC lenders increase the private share by $1.8 \%$ and the growth in marginal GSE by 3 to $4 \%$ in states with tougher APL rules. Higher growing OCC lenders offer cheaper loans than non-OCC lenders, while non-OCC lenders outcompete small growing national banks. When OCC lenders are deregulated, they take more risks and sell their loans on the secondary mortgage market. Tougher predatory lending laws have not reduced subprime lending and non- OCC lenders felt the impact of the law to a greater degree than OCC lenders. This paper is empirical and results are derived from reduced-form analysis. As a result, I cannot assess whether individual states with unique laws or all banks facing the same APL law would create more chaos in the secondary mortgage market. For future work, modelling heterogenous financial institutions with regional variation in the state law would help answer the welfare cost analysis.

\section{References}

Avery, R. B., Brevoort, K. P., \& Canner, G. B. (2006). Higher-priced home lending and the 2005 hmda data (table 8 revised september 18, 2006). Fed. Res. Bull. A123, 92.

Bostic, R. W., Engel, K. C., McCoy, P. A., Pennington-Cross, A., \& Wachter, S. M. (2008). State and local antipredatory lending laws: The effect of legal enforcement mechanisms. Journal of Economics and Business, 60(1), 47-66.

Di Maggio, M., \& Kermani, A. (2017). Credit-induced boom and bust. The Review of Financial Studies, 30(11), 37113758.

Ding, L., Quercia, R. G., Reid, C. K., \& White, A. M. (2012). The impact of federal preemption of state antipredatory lending laws on the foreclosure crisis. Journal of Policy Analysis and Management, 31(2), 367-387.

Elliehausen, G., \& Staten, M. E. (2004). Regulation of subprime mortgage products: An analysis of north carolina's predatory lending law. The Journal of Real Estate Finance and Economics, 29(4), 411-433.

Ernst,K.,Farris,J.,\&Stein,E.(2002).Northcarolina?ssubprimehomeloanmarketafter predatory lending reform. Center for ResponsibleLending.

Harvey, K., \& Nigro, P. (2003). How do predatory lending laws influence mortgage lending in urban areas? a tale of two cities. Journal of Real Estate Research, 25(4), 479-508.

Harvey, K. D., \& Nigro, P. J. (2004). Do predatory lending laws influence mortgage lending? an analysis of the north carolina predatory lending law. The Journal of Real Estate Finance and Economics, 29(4), 435-456.

Ho, G., \& Pennington-Cross, A. (2005). The impact of local predatory lending laws.

Ho, G., \& Pennington-Cross, A. (2006). The impact of local predatory lending laws on the flow of subprime credit. Journal of Urban Economics, 60(2), 210-228.

Ho, G., \& Pennington-Cross, A. (2007). The varying effects of predatory lending lawson high-cost mortgage applications. Finance Faculty Research and Publications, 9.

Quercia, R. G., Stegman, M. A., \& Davis, W. R. (2003). The impact of north carolina's anti-predatory lending law: A descriptive assessment. Center for Community Capital- ism, The Frank Hawkins Kenan Institute of Private Enterprise.

Saiz, A. (2010). The geographic determinants of housing supply. The Quarterly Journal of Economics, 125(3), 12531296. 